\title{
SAPITAN SEBAGAI MAKANAN TRADISIONAL KHAS PEKALONGAN
}

\author{
Budi Riyanto ${ }^{1}$, Fitri Abdillah ${ }^{2}$ \\ Universitas Agung Podomoro ${ }^{1}$ \\ Email: budi.riyanto@podomorouniversity.co.id \\ Universitas Agung Podomoro ${ }^{2}$ \\ Email: fitriadie@gmail.com
}

\begin{abstract}
Abstrak
Tujuan dari penelitian ini adalah untuk mengetahui filosofi, sejarah, budaya, cara membuat, dan memperbaharui kemasan Sapitan yang merupakan salah satu kuliner di Pekalongan agar dapat dikenal oleh masyarakat luas. Metode penelitian yang digunakan adalah metode deskriptif kualitatif dengan melakukan wawancara kepada pemerintah, masyarakat, dan pembuat sapitan. Lalu membuat reduksi data dengan cara membuat abstraksi. Dari penelitian ini ditemukan kalau sapitan tercipta antara akhir abad 18 atau awal abad 19. Sapitan tercipta karena pengaruh budaya dari Yogyakarta karena rasanya yang cenderung lebih manis. Sapitan merupakan perubahan dari makanan Yogyakarta yang bernama sanggar. Yang merupakan salah satu makanan yang digemari oleh Rajaraja jaman dulu yang menjadi kegemaran Sri Sultan Hamengkubuwono VIII hingga Sri Sultan Hamengkubuwono X. Nama sapitan memiliki arti daging yang dijepit, dan menggunakan batang pepaya sebagai penguncinya yang memiliki arti sebagai tolak bala. Dengan memperbaharui kemasan sapitan menjadi lebih kekinian diharapkan dapat meningkatkan daya belinya. Agar dikenal secara luas dan banyak dikonsumsi sampai ke luar Kota Pekalongan. Karena sapitan merupakan salah satu makanan khas Pekalongan yang perlu dipertahankan budayanya untuk mempertahankan kearifan budaya lokal.
\end{abstract}

\section{Kata kunci: Sapitan, Makanan Tradisional, Gastronomi}

\begin{abstract}
The purpose of this research is to find out the philosophy, history, culture, how to make, and renew the packaging of Sapitan is one of the culinary delights in Pekalongan so that it can be known by the wider community. The research method used is a qualitative descriptive method by conducting interviews with the government, the community, and the makers of siting. Then make data reduction by making abstractions. From this study it was found that sapitan was created between the late 18th or early 19th century. Sapitan was created because of cultural influences from Yogyakarta because it tended to be sweeter. Sapitan is a change from Yogyakarta food called sanggar. Which is one of the foods that are favored by ancient kings who became the favorite of Sri Sultan Hamengkubuwono VIII to Sri Sultan Hamengkubuwono X. The name sapitan has the meaning of meat that is clamped, and uses papaya stems as a lock which has the meaning of repelling reinforcements. Renewing the packaging of sapitan is more up to date and is expected to increase purchasing power. In order to be widely known and widely consumed outside Pekalongan City. Because sapitan is one of Pekalongan's special foods that needs to be preserved in its culture to maintain the wisdom of local culture.
\end{abstract}

Keywords: Sapitan, Indigenous culinary, Pekalongan 


\section{INTRODUCTION}

Sektor pariwisata saat ini sudah dijadikan sebagai bisnis unggulan nasional yang dapat memacu pertumbuhan ekonomi seperti membuka peluang untuk usaha dalam bidang kegiatan pariwisata. Penetapan pariwisata digunakan sebagai bisnis unggulan di Indonesia sesuai dengan laporan The World Travel and Tourism Council yang menyatakan bahwa Indonesia merupakan negara dengan pertumbuhan pariwisata yang paling baik jika dibandingkan negara-negara anggota G20 lainnya (Widadio, 2014).

Daya tarik pariwisata baru-baru ini berkembang ke gastronomi yang menjadi tujuan yang menarik wisatawan. Wisata gastronomi merupakan suatu cara yang memiliki fungsi sebagai pelestarian yang dilakukan oleh manusia melalui makanan. Objeknya adalah untuk memberikan bimbingan menurut prinsip-prinsip tertentu dengan tujuan agar semua orang mencari, menyediakan, atau menyiapkan makanan. Wisata gastronomi memberikan pengaruh ekonomi bagi banyak pihak, seperti: petani, peternak, nelayan, dan industri yang terkait dengan penyedia jasa makanan (Brillat-Savarin, 1994).

Destinasi pariwisata kuliner adalah kesatuan wilayah administrative yang memiliki satu atau lebih objek wisata kuliner lokal. Sedangkan objek wisata kuliner adalah kesatuan wilayah geografis di dalam kota yang memiliki satu atau lebih produk wisata kuliner lokal baik berupa restoran atau warung, pusat jajan, industri rumahan yang menampilkan tema kuliner tertentu dan berkaitan dengan kelokalan wilayahnya. Wisata kuliner adalah aktifitas wisatawan terkait makanan di destinasi pariwisata seperti makan di restoran, pembelian produk makanan lokal, dan menikmati pengalaman keunikan makan produksi lokal pada wilayah tertentu (Palupi, 2016). Sedangkan menurut Turgarini, kuliner tidak hanya dilihat sebagai objek pendukung di tempat tujuan tetapi juga bisa dikemas menjadi objek wisata (Turgarini dan Abdillah, 2016)

Pada saat ini kuliner juga menjadi salah satu daya tarik wisata. Dimana orang-orang akan datang untuk mencoba makanan yang hanya ada di tempat tersebut dengan pembuatan secara aslinya. Beberapa makanan khas di antaranya: sapitan atau capitan, megono, tauto, garang asem, nasi uwet, pindang tetel, dll.

Salah satu kulinernya terbilang unik yaitu sapitan. Sapitan merupakan daging yang sudah dibumbui kemudian dicepit dan dikunci dengan batang pepaya lalu dibakar. Prosesnya yang unik menjadikan sapitan menarik untuk dikonsumsi.

Seiring dengan perkembangan jaman, saat ini sapitan hanya dapat ditemui di Pekalongan. Banyak masyarakat yang masih belum mengenal sapitan. Seharusnya makanan dapat dijadikan sebagai warisan budaya yang harus dilestarikan agar tidak punah, oleh karenanya sangat penting untuk menjaga kelestarian dari makanan tersebut. Padahal sapitan adalah warisan budaya yang perlu dipertahankan sebagai upaya pelestarian kuliner nusantara. Selain itu kuliner merupakan bagian dari pengembangan pariwisata.

\section{Permasalahan}

Berdasarkan latar belakang, masalahnya adalah "Bagaimana menyusun profil sapitan atau capitan sebagai makanan unggulan khas Pekalongan?"

\section{Tujuan}

Berdasarkan pada pembahasan masalah di atas, maka tujuan penelitian adalah menyusun profil sapitan sebagaj makanan khas unggulan kota Pekalongan.

\section{METODOLOGI}

Penelitian ini menggunakan metode deskriptif dengan pendekatan kualitatif. Pendeketan kualitatif dipilih dalam penelitian ini untuk melihat esensi penelitian sehingga hasil yang diperoleh rinci dan detail. Penelitian ini berupaya untuk mengumpulkan, mengolah, 
menyusun penjelasan, dan mendokumentasikan data mengenai sapitan, selain itu juga mengungkapkan makna filosofi dari sapitan.

Instrumen penelitian atau alat penelitian yang digunakan di dalam mengumpulkan data dengan cara wawancara yang berbentuk pertanyaanpertanyaan, catatan observasi, dan dokumentasi.

Triangulasi merupakan teknik pemeriksaan keaslian suatu data yang memanfaatkan sesuatu yang lain. Di luar data untuk keperluan pengecekan atau sebagai pembanding terhadap data tersebut. Terdapat empat macam triangulasi sebagai teknik pemeriksaan yang memanfaatkan penggunaan sumber, metode, penyidik, dan teori (Moloeng, 2007). Triangulasi dilakukan melalui wawancara, observasi secara langsung dan observasi secara tidak langsung. Observasi secara tidak langsung berguna dalam bentuk pengamatan dari beberapa kelakuan dan kejadian yang kemudian dari hasil pengamatan diambil benang merah yang menghubungkan di antara keduanya. Teknik pengumpulan data yang digunakan akan melengkapi dalam memperoleh data primer dan skunder.

Data dikumpulkan dengan menggunakan teknik snowball sampling. Merupakan teknik pengumpulan sampel yang awalnya dengan jumlah kecil, dan kemudian menjadi besar. Apabila sudah mendapatkan semua data dari responden pertama, peneliti menanyakan rekomendasi kedua, dan seterusnya. Proses ini terus berlangsung sampai semua data cukup (Sugiono, 2010).

Analisis data dimulai dengan melakukan wawancara mendalam dengan narasumber kunci yaitu seseorang yang benar-benar memahami dan mengetahui situasi obyek penelitian. Setelah melakukan wawancara, analisis data dimulai dengan membuat transkrip hasil wawancara, dengan cara memutar kembali rekaman hasil wawancara, mendengarkan dengan seksama, kemudian menuliskan kata-kata yang didengar sesuai dengan apa yang ada direkaman tersebut. Setelah peneliti menulis hasil wawancara tersebut kedalam transkrip, selanjutnya peneliti harus membaca secara cermat untuk kemudian dilakukan reduksi data. Peneliti membuat reduksi data dengan cara membuat abstraksi, yaitu mengambil dan mencatat informasi-informasi yang bermanfaat sesuai dengan konteks penelitian atau mengabaikan kata- kata yang tidak perlu sehingga didapatkan inti kalimatnya saja, tetapi bahasanya sesuai dengan bahasa informan.

\section{Definisi Operasional Filosofi}

Menurut Kamus Besar Bahasa Indonesia, filosofi diartikan dengan filsafat. Filsafat adalah pengetahuan dan penyelidikan dengan akal budi mengenai hakikat untuk segala sesuatu yang ada, sebabnya, asalnya, dan hukumnya. Selain itu juga dapat diartikan sebagai teori yang mendasari dari alam pikiran atau suatu kegiatan (Sugono, 2008).

\section{Definisi Operasional Sejarah}

Sejarah adalah suatu susun cerita yang tidak dapat diubah atau direkonstruksi. Masa lalu manusia sebagian besar tidak dapat ditampilkan kembali. Biarpun orang tersebut memiliki ingatan tajam tidak akan dapat menyusun kembali masa lampaunya. Karena di dalam hidup tiap orang pasti memiliki peristiwa, otrang, kata-kata, pikiran-pikiran, tempattempat, dan bayangan-bayangan yang ketika terjadi sama sekali tidak menimbulkan kesan telah dilupakan (Gottschalk, 1975).

\section{Definisi Operasional Budaya}

Jika dilihat dari sudut pandang budaya makanan dapat mewakili nilai-nilai dan norma budaya pada masyarakat tersebut. Penelitian tentang bahan, cara masak, hingga penyajian makanan mempunyai aturan tertentu. Budaya berasal dari Bahasa Sansekerta yang memiliki arti Buddhayah. Buddayah merupakan kata bentuk jamak dari budhi 
(akal atau budi) yang memiliki arti sebagai hal-hal yang berkaitan dengan budi dan akal manusia. Dalam Bahasa Inggris, budaya/ culture berasal dari Bahasa Latin colere yang memiliki arti mengolah atau mengerjakan, utamanya mengolah tanah atau bertani (Koentjaraningrat, 2015).

\section{ESULT AND DISCUSSION Sejarah Sapitan}

Sapitan tercipta sekitar akhir abad 18 setelah perang Diponegoro. Tidak diketahui secara pasti tahun awal mula terciptanya Sapitan.Sapitan tercipta karena pengaruh budaya dari Yogyakarta. Dimana setelah perang Diponegoro terjadi lonjakan penduduk yang sangat pesat. Dikarenakan banyak orang-orang dari Keraton yang

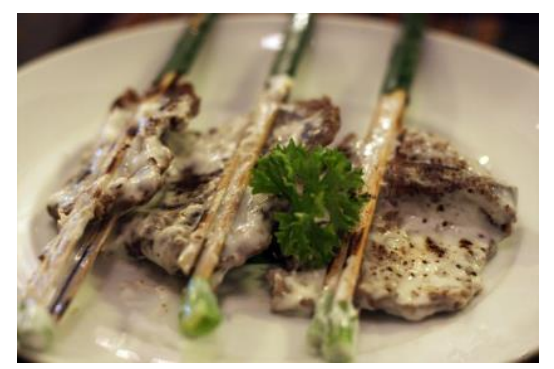

\section{Budaya Sapitan}

Gambar 1.1 Sanggar

Saat ini sapitan banyak ditemui warung megono lesehan sebagai teman makan megono. Awalnya sapitan dibuat dengan menggunakan daging sapi atau kerbau, karena saat itu ekonomi Pekalongan belum maju seperti saat ini. Dan kerbau dijadikan sebagai ternak dan melarikan diri ke Pekalongan dan menyembunyikan identitasnya. Dapat dilihat sapitan merupakan perubahan dari makanan Yogyakarta yang bernama sanggar. Sapitan dan sanggar banyak memiliki persamaan, terutama sama2 dijepit dengan bambu dan ada penguncinya. Rasa sapitan juga memiliki rasa yang dominan manis, sedangkan makanan Pekalongan memiliki rasa yang mayoritas adalah asin dan pedas. Sanggar sendiri merupakan salah satu makanan yang digemari oleh Raja-raja jaman dulu yang menjadi kegemaran Sri Sultan Hamengkubuwono VIII hingga Sri Sultan Hamengkubuwono X. Ilustrasi sanggar dapat dilihat dalam gambar berikut:

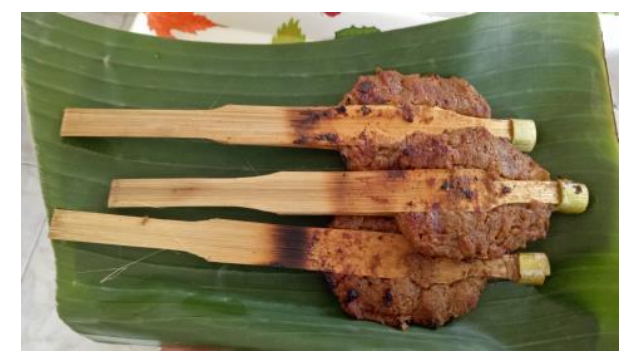

Gambar 1.2 Sapitan

membajak sawah. Tetapi saat ini ada yang membuat sapitan dengan menggunakan daging ayam dengan tujuan agar harga jualnya lebih murah dan dapat terjangkau oleh semua kalangan masyarakat. Ilustrasi sapidan dan megono yang dijual di warung megono lesehan:

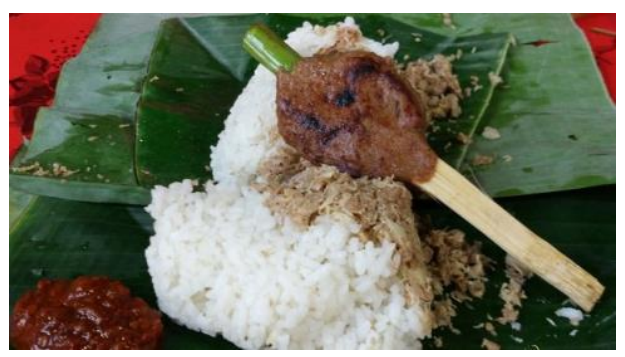

Gambar 1.3 Nasi Megono dan Sapitan

\section{Proses Pembuatan}

Cara membuat Sapitan adalah dengan merebus daging kaki sapi bagian belakang dengan menggunakan garam, lengkuas, asem, daun salam, dan gula sampai empuk. Tunggu daging sampai dingin. Gunakan blender untuk bumbu: ketumbar, jinten, bawang merah, bawang putih, kemiri, kunyit, laos, daun salam, gula merah, dan ebi. Kemudian ditumis 
sampai harum. Panaskan santan lalu ambil bagian kentalnya saja. Campurkan santan kentalnya ke bumbu yang sudah ditumis. Daging yang sudah dingin disuwir lalu dicepit menggunakan tusukan bambunya. Oleskan bumbu yang sudah jadi ke daging yang sudah dicepit. Lalu panggang sampai warnanya kecoklatan

\section{Kandungan Gizi Sapitan}

Bahan utama dalam pembuatan sapitan adalah daging sapi dan santan kental. Dalam 100 gr daging sapi mengandung: air $66,0 \mathrm{gr}$; protein $18,8 \mathrm{gr}$; energi 207,0 kal; lemak 14,0 gr; kalsium $11,0 \mathrm{mg}$; besi 2,8 mg; vitamin A 30,0 SI (hasbullah, 205).

Sedangkan kandungan dalam 100 gr santan: kalori $324 \mathrm{kal}$; protein 4,2 gr; lemak 34,3 gr; karbohidrat 5,6 gr; kalsium $14 \mathrm{mg}$; phosphor 1,9 mg; air 54,9 gr (Prihatini, 2008).

\section{Penyajian}

Di Pekalongan awalnya sapitan digunakan sebagai isi dari nasi berkat yang biasa digunakan sebagai bingkisan dalam suatu acara syukuran yang memiliki arti sebagai simbol kemewahan. Tidak ada aturan untuk jumlah dari nasi berkat, tergantung dari kemampuan ekonomi bagi yang mengadakan acara tersebut. Isi dari nasi berkat dapat berupa: megono, sapitan, acar timun, tekur, tempe kering, ikan asin goreng tepung, dll. Karena sebagai simbol kemewahan, sapitan juga disajikan untuk tamu kehormatan dan juga dijadikan sebagai oleh-olehnya.

\section{Pengembangan Sapitan Sebagai Kuliner Unggulan Khas Kota Pekalongan}

Kemasan sapitan pada saat ini hanya sebatas tempat mika dan kotak dari bahan kertas tebal yang sudah diberi nama. Pada pedagang megono lesehan hanya disajikan dengan menggunakan piring anyaman yang sudah dilapisi dengan daun pisang. Dengan memperbaharui kemasan sapitan dengan harapan dapat dijadikan sebagai oleh-oleh. Sehingga sapitan dapat menjadi kuliner unggulan khas Kota Pekalongan.

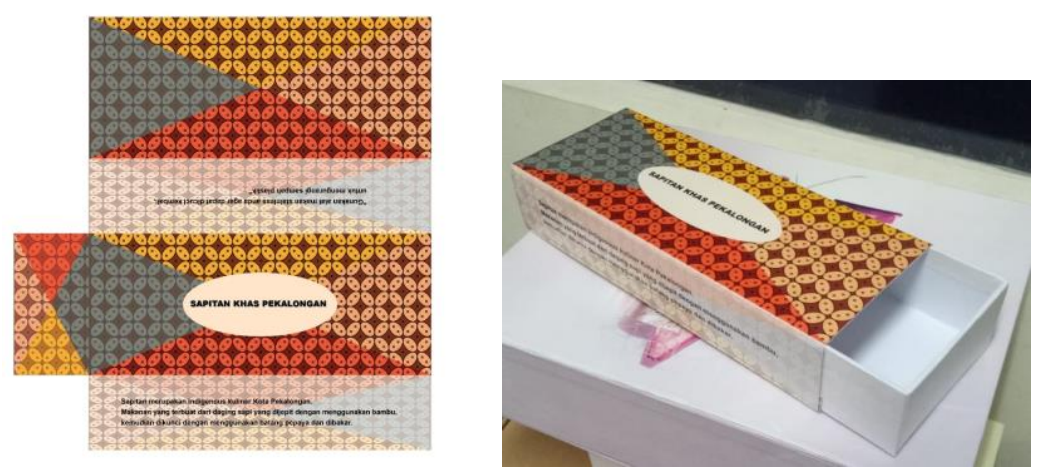

Gambar 1.4 Kemasan Sapitan

\section{SIMPULAN DAN SARAN}

\section{Kesimpulan}

Sapitan merupakan makanan khas Pekalongan dan hanya dapat ditemui di Kota tersebut. Merupakan daging yang dijepit sehingga namanya menjadi sapitan. Bentuknya yang unik yaitu daging yang dijepit menggunakan bambu dan dikunci dengan menggunakan batang pepaya. Penggunaan batang pepaya sebagai penguncinya memiliki arti sebagai tolak bala. Jadi pada saat acara syukuran dengan harapan selamat dan tidak terjadi apapun.
Saran

Banyak sekali kebudayaan yang dimiliki Indonesia seharusnya membuat kita bangga dan menghargai kebudayaan kita. Seharusnya generasi muda juga ikut membudayakan dan melestarikan kebudayaan asli Indonesia agar dapat lebih dikenal secara luas. Karena umumnya masyarakat Indonesia merasa lebih bangga terhadap budaya asing. Perlunya pengenalan budaya asli Indonesia agar menjadi lebih bangga terhadap budaya sendiri seperti sapitan. 
Selain itu juga perlunya melakukan acaraacara kuliner yang mengangkat budaya kuliner lokal. Dan juga meningkatkan kebanggaan terhadap kuliner Indonesia. Dan mengadakan seminar dan sejenisnya agar sapitan menjadi mendunia.

\section{DAFTAR PUSTAKA}

Brillat-Savarin, J. A. (1914), The Physiology of Taste, Penerjemah: A. Drayton, Harmondsworth: Penguin.

Gottschalk, Louis (1975), Mengerti Sejarah, terjemahan Nugroho Notosusanto. Jakarta: Universitas Indonesia.

Hasbullah (2005), Pengolahan Pangan. Sumatera Barat: Dewan Ilmu Pengetahuan Teknologi an Industri Sumatera Barat.

Koentjaraningrat (2015), Kebudayaan Mentalitas Dan pembangunan, Jakarta: Kompas Gramedia.

Moleong, L. J. (2007), Metodologi Penelitian Kualitatif. Bandung: PT Remaja Rosdakarya Offset.
Palupi, S. (2016), Naskah Potensi Wisata Kuliner dan Spa. Jakarta: Pengembangan Destinasi dan Industri Pariwisata.

Prihatini, R. I. (2008), Analisa Kecukupan Panas Pada Proses Pasteurisasi Santan. Bogor: Fakultas Teknologi Pertanian IPB.

Sugiono (2010), Metode Penelitian Kuantitatif Kualitatif dan R \& D. Bandung: CV. Alfabeta.

Sugono, Dendy (2008), Kamus Bahasa Indonesia. Jakarta: Pusat Bahasa Departemen Pendidikan Nasional.

Turgarini, Dewi \& Abdillah, Fitri (2016), Local Culinary: Tourist Attractions Vs Cultural Identity. Bali: Promoting Cultural \& Heritage Tourism.

Widadio, N. A. (2014), Menparekraf: Perkembangan Pariwisata Indonesia Paling Bagus. Kompas. http://travel.kompas.com/read/2014/ 04/02/0949478/Menparekraf.Perkem bangan.Pariwisata.Indonesia.Paling. $\underline{\text { Bagus }}$ 